\title{
Distribution of Corticotropin Releasing Hormone in the Fetus, Newborn, Juvenile, and Adult Baboon
}

\author{
SUSAN A. DOTZLER, ROBERT J. DIGERONIMO, BRADLEY A. YODER, AND \\ THERESA M. SILER-KHODR \\ Wilford Hall Medical Center, San Antonio, Texas 78236, U.S.A. [S.A.D., R.J.D.], University of Texas \\ Health Science Center, San Antonio, Texas 78229, U.S.A. [B.A.Y., T.M.S.-K.]
}

\begin{abstract}
ABST
Corticotropin releasing hormone (CRH) has previously been
identified in extrahypothalamic tissues and may act in a paracrine
fashion within these tissues. To date, CRH production and its
role in the fetus and newborn have not been investigated. The
aim of this study was to explore the distribution and ontogeny of
CRH in extrahypothalamic tissues of the fetus, newborn, juve-
nile, and adult baboon. Pituitary, adrenal, kidney, liver, and lung
tissues from baboons at 125 d gestation, 140 d gestation, $185 \mathrm{~d}$
gestation (term), juveniles, and adults were obtained at necropsy.
The tissues were quantified for protein and immunoreactive CRH
was determined by a RIA. CRH levels were normalized to the
protein content of each tissue. CRH was present in all tissues and
varied over a 100 -fold range according to tissue type. The highest
concentration of CRH was found in the pituitary, which did not
differ with the gestation and/or age of the animal. In the lung
tissues of $125-$ and 140 -d gestation animals, CRH was greater
than the term, juvenile, and adult lung ( $p<0.02$ ). CRH in the
\end{abstract}
CRH is a 41-amino acid neuropeptide first characterized from the hypothalami of sheep (1). The cell bodies of the neurons that synthesize $\mathrm{CRH}$ are located mainly in the paraventricular nucleus of the hypothalamus. $\mathrm{CRH}$ is conducted to the median eminence, where it is transported to the anterior pituitary to promote the production of ACTH. ACTH is then released into the blood and acts upon the adrenal cortex to produce cortisol (2). This endocrine axis regulates carbohydrate and amino acid metabolism, maintains blood pressure, and modulates and restrains the inflammatory response (3). In

Received April 16, 2003; accepted July 31, 2003.

Correspondence: Susan Dotzler, M.D., Department of Pediatrics, Wilford Hall Medical Center, 2200 Berquist Dr., Suite 1, Lackland AFB, TX 78236, U.S.A., e-mail: susan.dotzler@lackland.af.mil

Supported by the Air Force Surgeon General Fund and National Heart, Lung, and Blood Institute grant HL52636-06.

The opinions expressed in this article are solely those of the authors and do not represent the views of the United States Air Force, Department of Defense, or the United States Government.

DOI: 10.1203/01.PDR.0000100460.00639.F4 adrenal gland of the 125-d samples was greater than the other four ages tested $(p<0.02)$. Liver CRH levels were higher in the term animals compared with the juvenile baboons. Our study documents the existence of $\mathrm{CRH}$ in extrahypothalamic tissues of the baboon from $125 \mathrm{~d}$ of gestation to adulthood. Given its presence and distribution, we speculate that $\mathrm{CRH}$ may exert ongoing paracrine and/or autocrine actions in these tissues from the time of intrauterine life throughout adulthood. (Pediatr Res 55: 120-125, 2004)
Abbreviations
CRH, corticotropin releasing hormone
irCRH, immunoreactive corticotropin releasing hormone
irACTH, immunoreactive ACTH hormone
DHEA-S, dehydroepiandrosterone sulfate
POMC, proopiomelanocortin

the fetus, cortisol is essential for normal fetal tissue maturation and survival (4).

In addition to classical hypothalamic $\mathrm{CRH}$ production, extrahypothalamic secretion of CRH has been identified. In 1982, irCRH in placenta extracts was found (5), and it is now known that the placenta and fetal membranes of primates synthesize $\mathrm{CRH}(6,7)$. The role of placenta CRH has been studied and is likely involved in vasoregulation in the placenta and ultimately in parturition $(8,9)$. Extrahypothalamic $\mathrm{CRH}$ has also been identified in rats (10-14), mice (15), dogs (16), cows (17), baboons (18), monkeys (6), and humans (19-22). Some of the cell types in which irCRH and/or CRH mRNA expression have been identified include macrophages, tissue fibroblasts, endothelial cells, circulating monocytes, and lymphocytes (20, 23, 24). Furthermore, there is evidence that $\mathrm{CRH}$ may act in an autocrine/paracrine fashion to modulate inflammation $(25,26)$.

Moreover, glucocorticoid production stimulated by $\mathrm{CRH}$ appears necessary for normal lung development, inasmuch as the offspring of knockout mice with deficiencies of CRH die of pulmonary hypoplasia, and this was prevented by prenatal 
supplementation of glucocorticoids (27). Furthermore, it is well known that exogenous prenatal glucocorticoids have reduced the incidence and severity of respiratory distress syndrome and decreased the incidence of necrotizing enterocolitis, intraventricular hemorrhage, and mortality of the preterm infant (28-31). Prenatal steroids have also been found to accelerate the maturation of the lung and gastrointestinal enzyme systems $(32,33)$.

Little is known about the extrahypothalamic CRH in fetal and newborn tissues. Because we know that cortisol is essential for normal development of the fetus and that CRH has been identified in adult extrahypothalamic tissues, we have investigated for the presence of CRH in a number of extrahypothalamic tissues. In this study, we examined the distribution of irCRH in the pituitary, adrenal, lung, liver, and kidney in the fetus, newborn, juvenile, and adult baboon. The ontogeny of $\mathrm{CRH}$ among these tissues and across multiple ages was compared.

\section{MATERIALS AND METHODS}

Tissue samples. Tissues were obtained from the Primate Center at the Southwest Foundation for Biomedical Research in San Antonio, TX, U.S.A. Pituitary, adrenal, lung, liver and kidney samples were taken at necropsy from $125 \mathrm{~d}$ gestation, $140 \mathrm{~d}$ gestation, and $185 \mathrm{~d}$ gestation (term), as well as juvenile (ages 13-18 mo) and adult (ages 13-24 y) baboons (Table 1). Juvenile and adult animals were necropsied for various reasons, the most common being chronic diarrhea or part of a geriatric research protocol. There was one adult with chronic renal failure and one juvenile with seizures. All adult and juvenile tissues were placed in RNAlater (Ambion, Austin, TX, U.S.A.) at necropsy and frozen at $-20^{\circ} \mathrm{C}$ until homogenization. Term, 140-d gestation, and 125-d gestation samples were frozen in liquid nitrogen at necropsy, then placed in RNAlater and frozen at $-20^{\circ} \mathrm{C}$. Tissue weight was recorded before homogenization. All samples were homogenized in 2-4 $\mathrm{mL}$ of PBS, except the 125-d and 140-d gestation lung samples. The 125-d and 140-d gestation lung tissues were homogenized in lysis buffer $(140 \mathrm{mM} \mathrm{NaCl}, 10 \mathrm{mM}$ Tris-Cl, $\mathrm{pH} 8.0$, $15 \mathrm{mM} \mathrm{MgCl} 2,0.5 \%$ Nonidet P-40 with 1:1000 of $1: 10$ diethylpyrocarbonate in $100 \%$ ethanol). Because the recovery of CRH after extraction for the RIA was low using the lysis buffer, the buffer was switched to PBS. The lysis buffer and PBS buffer were compared on the same samples and yielded comparable results. Immediately after homogenizing, bacitracin, a protease peptidase inhibitor, $(50$ units $/ \mathrm{mL})$ was added. An aliquot $(0.1 \mathrm{~mL})$ was taken for protein quantification and the remaining homogenate was frozen at $-20^{\circ} \mathrm{C}$ until assay. An Institutional Review Board at Wilford Hall Medical Center approved all animal studies.

Protein. Protein content was determined using the PierceBCA Protein Assay Reagent (Pierce Chemical, Rockford, IL, U.S.A.). The protein recovery of the homogenate was compared with and without protein inhibitors pepstatin A, aprotonin, leupeptin, and phenylmethylsulfanyl fluoride and recovery was similar in each case. Thus, other than bacitracin, protein inhibitors were not included in the tissue extractions.

CRH extraction. CRH in the tissue homogenate was extracted from its binding protein using methanol, as previously described (34). Duplicate aliquots of homogenate $(500 \mu \mathrm{L})$ were mixed with methanol $(3.5 \mathrm{~mL})$. In the cases where 500 $\mu \mathrm{L}$ of homogenate was unavailable, the aliquot amount was mixed one to seven with methanol for the extraction. The mixture was placed at $-20^{\circ} \mathrm{C}$ for $20 \mathrm{~min}$ and then centrifuged at $4000 \mathrm{~g}$ for $15 \mathrm{~min}$ at $4^{\circ} \mathrm{C}$. The methanol fraction containing the CRH was decanted and dried using a Savant Speed-Vac. In each extraction, at least two control samples with a known amount of CRH were also extracted in duplicate to determine the recovery for each extraction set. The average extraction efficiency using this method for the PBS homogenization was $82 \%$. The average extraction efficiency using this method when lysis buffer was used was $34 \%$. The duplicate CRH extracts for each baboon tissue and the control sample were then assayed for $\mathrm{CRH}$ using a highly specific and sensitive RIA.

CRH RIA. The CRH RIA used a method similar to that reported by Sorem et al. (35). Antiserum from rabbits (a gift from Dr. Chrousos, National Institutes of Health, Bethesda, MD, U.S.A.) was used at a final concentration of $1 / 30,000$. After a 2 or $3 \mathrm{~d}$ incubation at $4^{\circ} \mathrm{C}$ with antiserum, radioiodinated Tyr-CRH, prepared by the method of Hunter and Greenwood (36) or purchased from Amersham Biosciences (Piscataway, NJ, U.S.A.), was added (10 pg/tube) to each tube. Standard CRH was purchased from Sigma Chemical (St. Louis, MO, U.S.A.). The incubation was continued for an additional $2-3 \mathrm{~d}$ at $4^{\circ} \mathrm{C}$. Bound and free hormone was separated using sheep anti-rabbit gamma globulin-conjugated magnetic beads (Polysciences, Warrington, PA, U.S.A.). The extraction buffers were tested with and without CRH stock solution and no nonspecific interactions were observed in the assay. The assay sensitivity (the concentration at $\pm 2 \mathrm{SD}$ of maximum binding) was at least $24 \mathrm{pg} / \mathrm{mL}$ after correction of extraction loss with an average sensitivity of $2.47 \mathrm{pg} /$ tube and, in the units expressed in this article, that is equivalent to 0.40 pg of $\mathrm{CRH}$ per $\mathrm{mg}$ of protein. There were no significant

Table 1. The number of tissues assayed by RIA by animal age and organ type in baboons

\begin{tabular}{cccccc}
\hline & \multicolumn{4}{c}{ Tissue } \\
\cline { 2 - 5 } Age & Pituitary & Adrenal & Lung & Liver & 5 \\
Kidney \\
$125 \mathrm{~d}$ & 5 & 5 & 4 & 5 & 5 \\
$140 \mathrm{~d}$ & 5 & 4 & 3 & 5 & 5 \\
Term & 5 & 5 & 4 & 3 & 3 \\
Juvenile & 3 & 3 & 10 & 7 & 6 \\
Adult & 5 & 7 & 10 & \\
\hline
\end{tabular}

125 d, 125-d gestation; 140 d, 140-d gestation; term, 185-d gestation; juvenile, 13-18 mo; adult, 13-24 y. 
cross-reactions $(<0.01 \%)$ for the following peptides: luteinizing hormone releasing hormone (LHRH), growth hormonereleasing hormone $(\mathrm{GHRH})$, thyrotropin-releasing hormone $(\mathrm{TRH})$, somatostatin, substance $\mathrm{P}$, vasoactive intestinal peptide, human ACTH, $\beta$-endorphin, melanocyte-stimulating hormone (MSH), vasopressin, and oxytocin (37). After correcting for the extraction, the intra- and interassay coefficients of variation were $8 \%$ and $14 \%$, respectively.

Statistical analysis. The tissue CRH concentration was normalized using the protein content of the tissue and the result was reported as picograms of $\mathrm{CRH}$ per milligrams of protein content $(\mathrm{pg} / \mathrm{mg})$. Statistical significance for differences in results between tissue types and among all age groups was evaluated by univariate ANOVA for repeated measures. If significant, a Tukey's multiple comparison test was used to determine the specific differences. A $p$ value of $<0.05$ was considered significant. Results are reported as the mean \pm SEM.

\section{RESULTS}

CRH was found in all tissues examined and at all ages examined. The highest concentration of $\mathrm{CRH}$ as well as the greatest variance was observed in the pituitary; however, pituitary CRH concentrations did not differ significantly with the age of the animal (Fig. 1). The mean concentrations in the pituitary ranged from $313 \pm 124$ to $542 \pm 167 \mathrm{pg} / \mathrm{mg}$. The concentration in the lung of the 125-d and 140-d gestation baboons was the next highest, yet less than $1 / 10$ of the pituitary. CRH in the lung of the 125-d and 140-d gestation animals was greater than that found in term $(p<0.02)$, juvenile $(p<0.01$ ), or adult ( $p \leq 0.001$ ) baboons (Fig. 2). $\mathrm{CRH}$ in the adrenal gland was also statistically higher in the 125-d gestational animals than the other four ages studied $(p<$ 0.02) (Fig. 2). There was a low but relatively constant level of $\mathrm{CRH}$ found in the kidney, and this did not differ with the age of the animal. The liver also displayed low but detectable amounts of $\mathrm{CRH}$, however, in term animals, liver CRH was significantly greater than in the juvenile animals (Fig. 2).

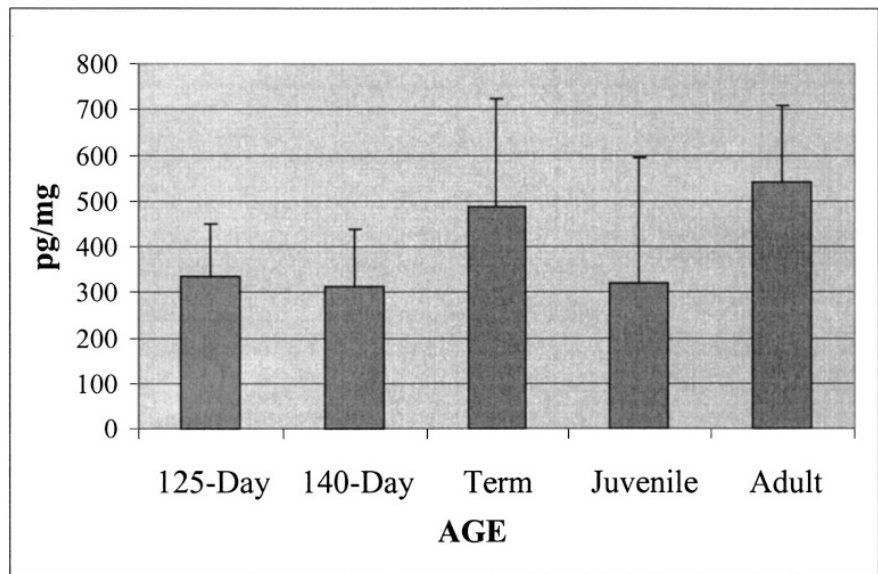

Figure 1. $\mathrm{CRH}(\mathrm{pg} / \mathrm{mg}$ protein, mean $\pm \mathrm{SEM})$ in pituitary samples at each age studied is shown. 125-Day $=125$-d gestation baboons $(n=5), 140$-Day $=140-\mathrm{d}$ gestation $(n=5)$, term $=185-\mathrm{d}$ gestation $(n=5)$, juvenile $(n=3)$, and adult $(n=5)$. No significant differences among ages were found.

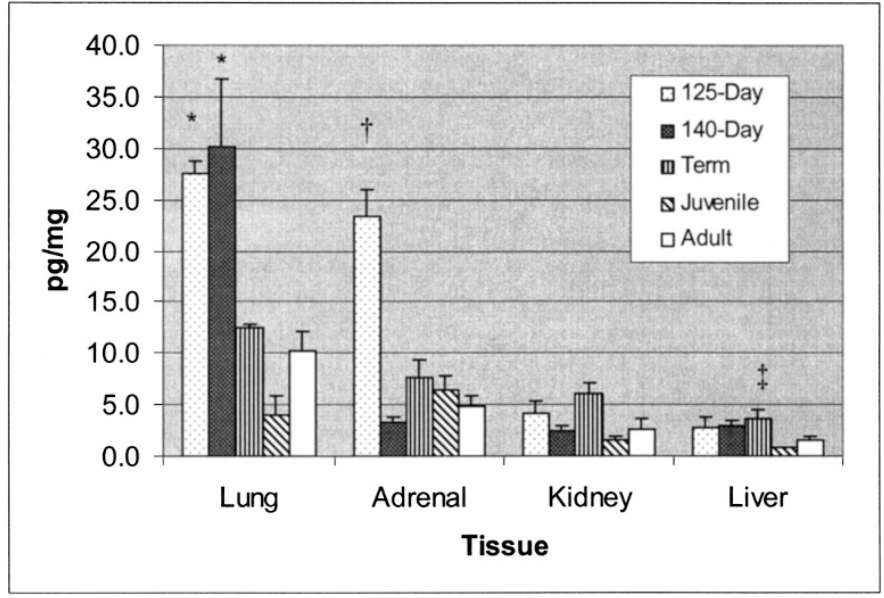

Figure 2. $\mathrm{CRH}(\mathrm{pg} / \mathrm{mg}$ protein, mean $\pm \mathrm{SEM})$ of each age group for a given tissue is shown. 125-Day $=125-\mathrm{d}$ gestation baboons, 140-Day $=140-\mathrm{d}$ gestation. *The lung of the 125-d $(n=4)$ and 140-d $(n=3)$ animals was significantly greater than the term $(n=4)$, juvenile $(n=4)$, and adult $(n=10)$ animals. There were no differences between ages in the kidney $(n=5$ for 125-d, 140-d, and term; $n=3$ for juvenile; $n=6$ for adult animals). $\dagger$ The adrenal gland of the 125-d baboons $(n=5)$ was significantly greater than the other ages $(p<0.02)(n=4$ for $140-\mathrm{d}, n=5$ for term, $n=3$ for juvenile, $n$ $=7$ for adult animals). $\$$ The liver of the term $(n=5)$ baboon was significantly greater than the liver of the juvenile $(n=3)$ baboons $(p<0.03)$.

When CRH was compared by tissue type at a given age, the pituitary CRH was greatest at all ages. CRH in the adrenal and lung of the 125-d gestation animal was statistically higher than the liver or kidney at that same gestational age $(p<0.01)$ (Fig. 3 ). The mean lung CRH values in the 140-d baboons were greater than those found in the liver, kidney, or adrenal. The amount of $\mathrm{CRH}$ in the term lung, with a mean value $12.5 \pm$ $1.89 \mathrm{pg} / \mathrm{mg}$ was significantly greater than that found in the term kidney $(p<0.04)$ and liver $(p<0.004)$ but was not different from the term adrenal. There were no significant differences in

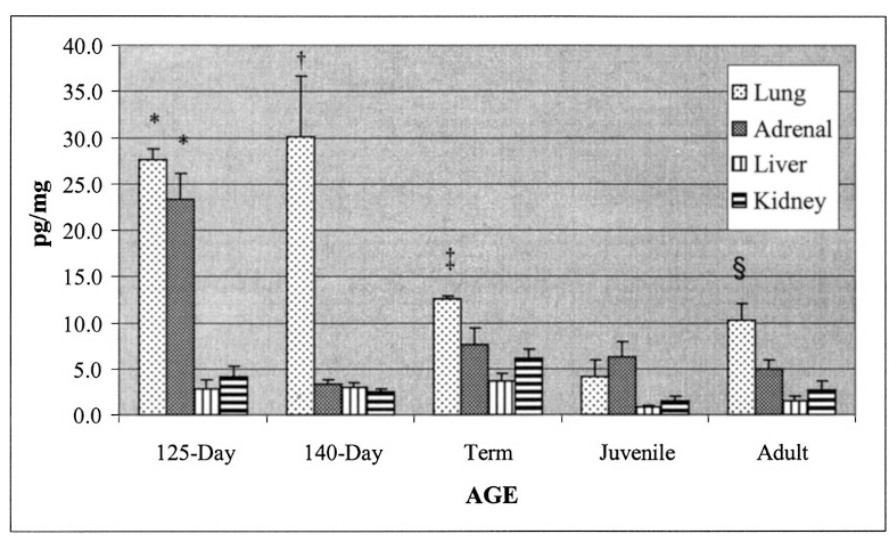

Figure 3. $\mathrm{CRH}$ (pg/mg protein, mean $\pm \mathrm{SEM}$ ) in lung, adrenal, liver, and kidney for each given age studied is shown. 125-Day $=125$-d gestation baboons, 140-Day $=140$-d gestation. $*$ The 125-d lung $(n=4)$ and adrenal $(n$ $=5)$ were significantly higher than 125-d liver $(n=5)$ and kidney $(n=5)$. $\dagger$ The 140-d lung ( $n=3)$ was significantly higher than the 140-d adrenal $(n=$ $4)$, liver $(n=5)$, and kidney $(n=5)$. $\$$ The term lung $(n=4)$ was significantly greater than the term liver $(n=5)$ and kidney $(n=5)$. There were no statistical differences in the juvenile group ( $n=3$ for adrenal, liver, and kidney; $n=4$ for lung). §The adult lung ( $n=10)$ was significantly greater than the adult liver $(n=7)$. 
$\mathrm{CRH}$ among tissue types in the juvenile animals. In the adult, $\mathrm{CRH}$ in the lung was significantly greater than that found in the adult liver $(p<0.04)$ but not the kidney or adrenal (Fig. 3).

\section{DISCUSSION}

We have successfully demonstrated the presence of irCRH in the liver, lung, adrenal, kidney, and pituitary throughout a timeline from mid-gestation to adulthood in our baboon model. This is the first study investigating the ontogeny of irCRH in the primate. These findings are consistent with the report of Suda et al. (19) describing irCRH in the adrenal, lung, liver, and pituitary in human adults. Our findings show that the pituitary, which contained the pituitary stalk, had the greatest levels and was at least 10 -fold greater than any other tissue tested. In Suda's study, irCRH found in the human adults was also greatest in the pituitary and pituitary stalk and the levels in the other tissues (liver, kidney, lung, and adrenal) were at least 10 -fold lower than the pituitary stalk (19). In our study, we demonstrated low but detectable levels of irCRH in the kidney, which differs from previous work in adult humans in which irCRH was not detectable (19). However, the sensitivity of our method may have allowed for detection of very low concentrations of CRH.

The pituitary had the greatest quantity of irCRH, although there were no differences across the ages. It cannot be ascertained from these studies whether $\mathrm{CRH}$ is locally produced in the pituitary or stored in the pituitary and produced elsewhere. However, CRH mRNA in mice has been identified in the anterior pituitary, indicating that at least some CRH may be synthesized in the pituitary (15). Further studies to evaluate for mRNA of $\mathrm{CRH}$ in the pituitary may help to elucidate this finding.

Interestingly, the lung of the 125-d and 140-d gestation baboons contained appreciably more irCRH than the term, juvenile, and adult lung samples. This result is similar to that found in limited ontogeny data for CRH in the murine model. CRH mRNA has been shown in the fetal lung of the preterm mice at multiple gestational ages but was not detected in term animals (38). The reason for this difference may be that $\mathrm{CRH}$ has a developmental role in lung maturation. As described before, in CRH-deficient knockout mice the offspring die of lung dysplasia (27). Furthermore, prenatal steroids promote lung development (28). These findings suggest the importance of cortisol, the ultimate product of $\mathrm{CRH}$ action, via $\mathrm{ACTH}$, in lung maturation and development. In previous studies of fetal lung explants of baboons (125 d), CRH induces surfactant phospholipid synthesis, indicating a functional role for $\mathrm{CRH}$ in the fetal lung (39). irACTH has also been reported in fetal and adult ovine lung (40). Furthermore, it has been shown that the ovine lung can independently secrete and clear irACTH into and from the plasma (40). In addition, it is well known that lung tumors are a principal cause of ectopic ACTH synthesis. However, POMC RNA (the polypeptide precursor to ACTH) is also present in normal human lungs (41). CRH may act to regulate locally produced ACTH. These studies as well as the finding of greater concentrations of irCRH in the fetal lung suggest that CRH may be involved in maturation of the fetal lung. Evaluation of prenatal cell function as well as immunohistochemistry would be important to help further define the role of CRH in lung development.

CRH in the adrenal gland was higher in the 125-d gestation baboons compared with the 140-d gestation, term, juvenile, and adult baboons. This finding suggests that CRH may be more important in early gestation and may play a role in fetal adrenal development. The primate fetal adrenal undergoes a complex series of maturational changes that continue after birth. This development includes the fetal zone (which regresses after birth), the transitional zone (later to become the zona fasciculata) and the definitive zone (later to become the zona glomerulosa). The ontogenesis of enzyme and steroid production has been studied, with the human fetal adrenal cortex producing DHEA-S as early as $8-10$ wk gestation (42). It is still unknown as to when in gestation the fetal adrenal cortex has the functional ability to produce cortisol, although it is thought to occur mainly in the definitive zone (42). Studies of human fetal adrenal tissue in vitro have demonstrated that the adrenal is responsive to ACTH and can produce corticoids and DHEA-S as early as the 10th week of gestation (42). However, it is thought that the fetal adrenal has limited ability to produce cortisol de novo from cholesterol because of limited expression of the necessary enzymes until about $30 \mathrm{wk}$ gestation. It is suggested that the fetal adrenal may use other substrates such as progesterone to make cortisol (42). Other studies in primates have suggested that fetal conversion of placental progesterone to cortisol is minimal (43). Pepe and Albrecht (43) have shown that placental cortisol at midgestation exceeds placental cortisone and proposed that placental cortisol crosses into the fetal circulation and suppresses baboon ACTH production. Toward late gestation, placental estrogen derived from DHEA-S leads to the conversion of cortisol to its less active form, cortisone, which leads to a decrease in the fetal serum cortisol, causing an increase in fetal ACTH, which subsequently causes an increase in fetal adrenal production of fetal DHEA-S and cortisol (43). Elevated irCRH at $125 \mathrm{~d}$ gestation may suggest that CRH stimulates the maturation of the adrenal gland.

The liver of the term animals had significantly more $\mathrm{CRH}$ than that found in the juvenile animals. However, the levels in the liver are relatively low compared with the other tissues tested. The significance or relevance of this finding is unclear.

There are several theories for the source of the irCRH. The first is that it could be simply serum CRH from either the hypothalamus or, in the case of fetal baboons, it may be produced by the placenta and transported to the fetal circulation. However, the placental transport of CRH to the fetus is at least 10 -fold lower than the maternal levels (44). The second possibility is that CRH may be produced locally within each of the tissues. In the glucagon-producing $\alpha$ cells in the stomach, small intestines, and pancreas, CRH has been identified immunohistochemically, suggesting local production (45). The third theory is that CRH may be produced within the immune cells. CRH has been identified in immune accessory cells (20). CRH mRNA and peptide have been identified in mononuclear cells (23), mouse splenic T-lymphocytes (15), rat peripheral leukocytes (13), and in human T-lymphocytes (24). Finally, CRH 
may also be produced and then secreted in the terminals of postganglionic sympathetic neurons. It has been demonstrated that CRH mRNA and peptide are found in the dorsal root and sympathetic ganglia $(20,46)$. Any one or combination of these theories could account for irCRH production.

Locally produced CRH may have paracrine or autocrine activity. Recent studies have suggested this type of function $(11,20,21,25,46-48)$. Placental CRH is known to have a variety of paracrine activities. These include placental activation of ACTH and prostaglandin secretion, as well as other paracrine and endocrine effects (9). Karalis and colleagues (25) demonstrated in a rat model that irCRH acted as an autocrine or paracrine inflammatory cytokine. In this study, irCRH was identified in experimentally produced inflammatory sites of rats and was not identified in noninflammatory sites. Serum levels were no different from control animals suggesting an autocrine or paracrine response. Furthermore, it appeared that the $\mathrm{CRH}$ in the inflammatory regions functioned as a proinflammatory agent differing from its typical immunosuppressive function. More recent work has also suggested a paracrine/ autocrine function for CRH. In 2001, both Kono et al. (47) and Sato et al. (21) have shown CRH to be locally produced in the skin and to be greater in inflammatory lesions, melanocytic nevus, seborrheic keratosis, and melanomas. In melanomas that produce $\mathrm{CRH}$, there was also expression of POMC, the precursor to ACTH as well as other hormones, suggesting an autocrine loop (21). Furthermore, in rat Leydig cells of the testis, it has been shown that CRH exerts an autocrine inhibition of testosterone biosynthesis (11).

This study demonstrates irCRH in extrahypothalamic tissues of the baboon from mid-gestation to adulthood. Given the presence of significantly elevated levels of CRH in the adrenal of the 125-d gestation baboon and elevated levels in the lung of the 125-d and 140-d gestation baboon, we speculate that CRH may play an especially important role in these tissues concerning their developmental regulation. Future studies including tissue evaluation for CRH mRNA and immunohistochemistry to identify cell types, as well as functional cell studies, will help to better understand the role of $\mathrm{CRH}$ in extrahypothalamic tissue at different maturational ages.

Acknowledgments. The authors thank the National Heart, Lung, and Blood Institute for support of the U10 Collaborative Program in Bronchopulmonary Dysplasia at the Primate Center at Southwest Foundation for Biomedical Research. We also thank Dr. Jacqueline Coalson, without whose support this work would not have been possible.

\section{REFERENCES}

1. Vale W, Spiess J, Rivier J 1981 Characterization of a 41-residue ovine hypothalamic peptide that stimulates secretion of corticotropin and $B$-endorphin. Science 213:1394-1397

2. Seasholtz A 2000 Regulation of adrenocorticotropic hormone secretion: lessons from mice deficient in corticotropin-releasing hormone. J Clin Invest 105:1187-1188

3. Miller WL, Chrousos GP 2001 Adrenal cortex. In: Felig P, Frohman LA (eds) Endocrinology and Metabolism, 4th ed. McGraw-Hill, New York, pp 387-391

4. Venihaki M, Carrigan A, Dikkes P, Majzoub J 2000 Circadian rise in materna glucocorticoid prevents pulmonary dysplasia in fetal mice with adrenal insufficiency. Proc Natl Acad Sci U S A 97:7336-7341

5. Shibasaki T, Odagiri E, Shizume K, Ling N 1982 Corticotropin-releasing factor activity in human placental extracts. J Clin Endocrinol Metab 55:384-386
6. Robinson BG, Arbiser JL, Emanuel RL, Majzoub JA 1989 Species specific placental corticotrophin releasing hormone messenger RNA and peptide expression. Mol Cell Endocrinol 62:337-341

7. Sasaki A, Tempst P, Liotta AS, Margioris AN, Hood LE, Kent SBH, Sato S, Shinkawa O, Yoshinaga K, Krieger DT 1988 Isolation and characterization of a corticotropin-releasing hormone-like peptide from human placenta. J Clin Endocrinol Metab 67:768-773

8. Campbell EA, Linton EA, Wolfe CDA, Scraggs PR, Jones MT, Lowry PJ 1987 Plasma corticotropin-releasing hormone concentrations during pregnancy and parturition. J Clin Endocrinol Metab 64:1054-1059

9. Petraglia F, Florio P, Nappi C, Genazzani AR 1996 Peptide signaling in human placenta and membranes: autocrine, paracrine and endocrine mechanisms. Endocr Rev 17:156-186

10. Thompson RC, Seasholtz AF, Herbert E 1987 Rat corticotropin releasing hormone gene: sequence and tissue-specific expression. Mol Endocrinol 1:363-370

11. Fabbri A, Tinajero JC, Dufau ML 1990 Corticotropin-releasing factor is produced by rat Leydig cells and has a major local antireproductive role in the testis. Endocrinology $127: 1541-1543$

12. Mastorakos G, Webster EL, Friedman TC, Chrousos GP 1993 Immunoreactive corticotropin-releasing hormone and its binding sites in the rat ovary. J Clin Invest 92:961-968

13. Aird F, Clevenger CV, Prystowsky MB, Redei E 1993 Corticotropin-releasing factor mRNA in rat thymus and spleen. Proc Natl Acad Sci U S A 90:7104-7108

14. Bruhn TO, Engeland WC, Anthony ELP, Gann DS, Jackson IMD 1987 Corticotropinreleasing factor in adrenal medulla. Ann N Y Acad Sci 512:115-128

15. Muglia LJ, Jenkins NA, Gilbert DJ, Copeland NG, Majzoub JA 1994 Expression of the mouse corticotropin-releasing hormone gene in vivo and targeted inactivation in embryonic stem cells. J Clin Invest 93:2066-2072

16. Bruhn TO, Engeland WC, Anthony ELP, Gann DS, Jackson IMD 1987 Corticotropinreleasing factor in the dog adrenal medulla is secreted in response to hemorrhage. Endocrinology 120:25-33

17. Minamino N, Uehara A, Arimura A 1988 Biological and immunological characterization of corticotrophin-releasing activity in the bovine adrenal medulla. Peptides 9:37-45

18. Goland RS, Wardlow SL, Fortman JD, Stark RI 1992 Plasma corticotropin-releasing factor concentration in the baboon during pregnancy. Endocrinology 131:1782-1786

19. Suda T, Tomori N, Tozawa F, Mouri T, Demura H, Shizume K 1984 Distribution and characterization of immunoreactive corticotropin-releasing factor in human tissues. J Clin Endocrinol Metab 59:861-866

20. Scopa CD, Mastorakos G, Friedman TC, Melachrinou M, Merino MJ, Chrousos GP 1994 Presence of immunoreactive corticotropin releasing hormone in thyroid lesions. Am J Pathol 145:1159-1167

21. Sato H, Nagashima Y, Chrousos GP, Ichihashi M, Funasaka Y 2002 The expression of corticotropin-releasing hormone in melanoma. Pigment Cell Res 15:98-103

22. Suda T, Tomori N, Tozawa F, Demura H, Shizume K, Mouri T, Miura Y, Sasano N 1984 Immunoreactive corticotropin and corticotropin-releasing factor in human hypothalamus, adrenal lung cancer, and pheochromocytoma. J Clin Endocrinol Metab 58:919-924

23. Stephanou A, Jessop DS, Knight RA, Lightman SL 1990 Corticotrophin-releasing factor-like immunoreactivity and mRNA in human leukocytes. Brain Behav Immun 4:67-73

24. Ekman R, Servenius B, Castro MG, Lowry PJ, Cederlund A, Bergman O, Sjogren HO 1993 Biosynthesis of corticotropin-releasing hormone in human T-lymphocytes. J Neuroimmunol 44:7-14

25. Karalis K, Sano H, Redwine J, Listwak S, Wilder RL, Chrousos GP 1991 Autocrine or paracrine inflammatory action of corticotropin-releasing hormone in vivo. Science 254:421-423

26. Crofford LJ, Sano H, Karalis K, Friedman TC, Epps HR, Remmers EF, Mathern P, Chrousos GP, Wilder RL 1993 Corticotropin-releasing hormone in synovial fluids and tissues of patients with rheumatoid arthritis and osteoarthritis. J Immunol $151: 1587-1596$

27. Muglia L, Jacobson L, Dikkes P, Majzoub JA 1995 Corticotropin-releasing hormone deficiency reveals major fetal but not adult glucocorticoid need. Nature 373:427-432

28. Crowley PA 1995 Antenatal corticosteroid therapy: a meta-analysis of the randomization trials, 1972 to 1994. Am J Obstet Gynecol 173:322-335

29. Leviton A, Kuban KC, Pagano M, Allred EN, Van Marter L 1993 Antenatal corticosteroids appear to reduce the risk of postnatal germinal matrix hemorrhage in intubated low birth weight newborns. Pediatrics 91:1083-1088

30. Bauer CR, Morrison JC, Poole WK, Korones SB, Boehm JJ, Rigatto H, Zachman RD 1984 A decreased incidence of necrotizing enterocolitis after prenatal glucocorticoid therapy. Pediatrics 73:682-688

31. Sinclair JC 1995 Meta-analysis of randomized controlled trials of antenatal corticosteroid for the prevention of respiratory distress syndrome: discussion. Am J Obstet Gynecol 173:335-344

32. Ballard PL 1989 Hormonal regulation of pulmonary surfactant. Endocr Rev 10:165-181

33. Moog F 1962 Developmental adaptations of alkaline phosphatases in the small intestine. Fed Proc 21:51-56

34. Holzman C, Jetton J, Siler-Khodr T, Fisher R, Rip T 2001 Second trimester corticotropin-releasing hormone levels in relation to preterm delivery and ethnicity. Obstet Gynecol 97:657-663

35. Sorem KA, Smikle CB, Spencer DK, Yoder BA, Grayson MA, Siler-Khodr TM 1996 Circulating maternal $\mathrm{CRH}$ and $\mathrm{GnRH}$ in normal and abnormal pregnancies. Am J Obstet Gynecol 175:912-916

36. Hunter W, Greenwood FC 1962 Preparation of iodine-131-labelled human growth hormone of high specific activity. Nature 194:495-496

37. Calogero AE, Bernardini R, Margioris AN, Bagdy G, Gallucci WT, Munson PJ, Tamarkin L, Tomai TP, Brady L, Gold PW, Chrousos GP 1989 Effects of serotoner- 
gic agonists and antagonists on corticotropin-releasing hormone secretion by explanted rat hypothalami. Peptides 10:189-200

38. Keegan CE, Herman JP, Karolyi J, O'Shea KS, Camper SA, Seasholtz AF 1994 Differential expression of corticotrophin-releasing hormone in developing mouse embryos and adult brain. Endocrinology 134:2547-2555

39. Emanuel RL, Torday JS, Asokananthan N, Sunday ME 2000 Direct effects of corticotrophin-releasing hormone and thyrotropin-releasing hormone on fetal lung explants. Peptides 21:1819-1829

40. Cudd TA, Wood CE 1995 Secretion and clearance of immunoreactive ACTH by fetal lung. Am J Physiol Endocrinol Metab 268:E845-E848

41. Texier PL, de Keyzer Y, Lacave R, Vieau D, Lenne F, Rojas-Miranda A, Verley JM, Luton JP, Kahn A, Bertagna X 1991 Proopiomelanocortin gene expression in normal and tumoral human lung. J Clin Endocrinol Metab 73:414-420

42. Messiano S, Jaffe RB 1997 Developmental and functional biology of the primate feta adrenal cortex. Endocr Rev 18:378-403
43. Pepe GJ, Albrecht ED 1990 Regulation of the primate fetal adrenal cortex. Endocr Rev 11:151-176

44. Goland RS, Tropper PJ, Warren WB, Stark RI, Jozak SM, Conwell IM 1995 Concentrations of corticotrophin-releasing hormone in the umbilical-cord blood of pregnancies complicated by pre-eclampsia. Reprod Fertil Dev 7:1227-1230

45. Orth DN 1992 Corticotropin-releasing hormone in humans. Endocr Rev 13:164-191

46. Udelsman R, Harwood JP, Millan MA, Chrousos GP, Goldstein DS, Zimlichman R, Catt KJ, Aguilera G 1986 Functional corticotropin releasing factor receptors in the primate peripheral sympathetic nervous system. Nature 319:147-150

47. Kono M, Nagata H, Umemura S, Kawana S, Osamura RY 2001 In situ expression of corticotropin-releasing hormone $(\mathrm{CRH})$ and proopiomelanocortin $(\mathrm{POMC})$ gene in human skin. FASEB J 15:2297-2299

48. Parker Jr CR, Stankovic AM, Goland RS 1999 Corticotropin-releasing hormone stimulates steroidogenesis in cultured human adrenal cells. Mol Cell Endocrinol $155: 19-25$ 